\title{
Netherton Sendromu ve Mental Retardasyon Birlikteliği
}

\section{Özet}

Netherton sendromu nadir rastlanan ve otozomal resesif geçişli bir iktiyoz tipidir. Bu sendromun ana belirtileri iktiyozis linearis sirkumfleksa, yapısal kıl gövdesi anomalisi (trikoreksis invajinata) ve atopik yatkınlıktır. Bazı hastalarda nadir olarak mental retardasyon da gözlenebilir. Bu yazıda mental retardasyonun eşlik ettiği bir Netherton sendromu olgusu sunulmaktadır.

Anahtar Sözcükler: Netherton sendromu; iktiyoz; mental retardasyon

\section{Abstract}

Netherton syndrome is a rare and autosomal recessive form of ichthyosis characterized by ichthyosis linearis circumflexa, trichorrhexis invaginata and atopic manifestations. Mental retardation may be also observed in some patients. We present here a rare case of Netherton syndrome with mental retardation.

Keywords: Netherton syndrome; ichthyosis; mental retardation

\section{Dilşad Yıldız Miniksar}

Malatya Devlet Hastanesi, Beydağı Kampüsü

Geliş Tarihi /Received : 26.03.2016 Kabul Tarihi /Accepted: 22.04.2016

Sorumlu Yazar/Corresponding Author Uzm. Dr. Dilşad Yıldız Miniksar Malatya Devlet Hastanesi,

Beydağı Kampüsü. Özalper Mah. Turgut Özal Bulvarı No:4

E-mail:dr_dilsad1984@hotmail.com 


\section{Gíiş}

İktiyozlar, hiperkeratoz ve/veya kepeklenmenin eşlik ettiği deskuamasyon bozukluğu ile karakterize genetik dermatozlardır (1). Sendromik iktiyozlardan olan Netherton sendromu (NS) nadir rastlanan ve otozomal resesif geçişli bir iktiyoz tipidir. Yaygın olarak SPINK5 gen mutasyonu bildirilmektedir (2). İnsidansının yaklaşık olarak 1/200.000 civarında olduğu tahmin edilmektedir (3). Bu sendromun ana belirtileri iktiyozis linearis sirkumfleksa, yapısal kıl gövdesi anomalisi ve atopik yatkınlıtır. Bazı hastalarda aminoasidüri, gelişme geriliği ve hücresel bağışıklık sistemi bozuklukları gözlenebilir $(2,4)$. Bu sendromda görülebilecek diğer bazı semptomlar ise; hipoalbüminemi enteropati ve mental retardasyondur (2).

Bu raporda akraba evliliği sonucunda dünyaya gelen ve NS tanısıyla beraber mental retardasyonun eşlik ettiği 6 yıl 8 ay yaşındaki bir erkek çocuğa dair vakanın literatür eşliğinde tartışılması amaçlanmıştır.

\section{OLGU}

Vaka konusu algılamada zayıflık şikayetiyle öğretmeni tarafından polikliniğimize yönlendirilen, NS tanısı ile dermatoloji ve genetik anabilim dallarında takip edilen, anne ve babası teyze çocukları olan 6 yıl 8 ay yaşındaki erkek hasta idi. Anne ve babasından sözlü ve yazılı onam alındı. Alınan anamnezle hastanın ilkokul birinci sınıf eğitiminin yarısını tamamlamasına rağmen harfleri tanımadığı, okumaya geçemediği için öğretmeninin önerisi üzerine tarafımıza yönlendirildiği öğrenildi.

Yapılan psikiyatrik muayenesinde bilincinin açı, koopere oryante olduğu, algılama ve yargilamasının yaşıtlarından geri olduğu, bazı harfleri net olarak söyleyemediği için konuşmasının anlaşılmaz olduğu, harfleri bilmediği, renkleri karıştırdığı fiziksel gelişiminin yaşıtlarıyla benzer olduğu gözlendi. Hastada zihinsel gerilik düşünülmekle birlikte herhangi bir davranış probleminin eşlik etmediği tespit edildi. Saçlarının seyrek, kuru ve cansız olduğu ve aynı zamanda alopesik alanların yaygınlığı dikkat çekmekteydi.

Öyküsünde prenatal ve natal dönemde özellik olmadığ ${ }^{\text {, }}$ postnatal dönemde alerjik astım tanısıyla takip edildiği, çok sık ÜSYE öyküsü olduğu, motor gelişiminin yaşıtlarından geri olduğu, ilk kelimeleri- ni 3 yaşında söylediği, 2 yaşında yürüdüğü öğrenildi. Hasta, 35 yaşında çiftçilikle uğraşan bir baba ve 32 yaşında ev hanımı olan bir annenin dört çocuğundan en küçüğü. Diğer üç kardeşi sağlıklı olan hastanın NS tanısı alan bir erkek kardeşinin 9 aylıkken öldüğü öğrenildi. Anne ve baba ölüm sebebinin gribal enfeksiyon olduğunu, ancak tam netlik kazanmadığını belirtti. Olgunun soygeçmişi de göz önüne alınarak genetik yatkınlıkla bağlantılı olarak SPINK gen mutasyonlarına yönelik incelemesinin yapıldığı, genetik bölümü tarafından da Netherton sendromu olarak kabul edildiği öğrenildi.

Zekasını ölçmek için hastaya yapılan WISC-R (Wechsler Çocuklar için Zeka Ölçeği) testinde toplam puanının 50-69 aralığında olduğu tespit edildi. Hastaya DSM-IV tanı ölçütlerine dayanarak hafif derecede mental retardasyon tanısı konularak, özel eğitim kurumları tarafından desteklenmesi amacıyla özel eğitim raporu düzenlendi.

\section{TARTIŞMA}

Olgumuz nadir görülen genetik bir cilt hastalığ olan NS’nin aslında psikiyatrik yönünün de varlığını vurgulaması açısından önemlidir. Çok farklı iktiyoz tabloları birbirlerinden klinik, histolojik ve genetik özellikleri ile ayrılırlar. İktiyozların klinik olarak ortak özellikleri derinin pullu görünümüdür. Lokalize veya yaygın olabilir. Kepekler farklı görünümlerde ve renklerde olabilir. Bazen sistemik bulgular tabloya eşlik ederek bir sendromun parçası olabilir. Hastalık genellikle doğuştan vardır, ama bir süre sonra da ortaya çıkabilir. Aile bireylerinin muayenesi de önemlidir. Anne-baba akrabalığı resesif geçişi gösterir. Hasta ebeveyn ve hasta kardeşler ise otozomal dominant geçişi göstermektedir (5-7). Doğumda veya ilk birkaç ay içinde olmak üzere yenidoğan döneminde ortaya çıktığında yüksek mortaliteli bir sendromdur. İlk deri belirtileri yaygin eritem ve kepeklenmedir. Daha sonra ise gövde ve ekstremitelerde yaygın, polisiklik, migratuar eritem, serpijinöz plaklar şeklinde kendisini gösterir. Polisiklik ve eritemli lezyonların kenarları hiperkeratotik çift kenarlıdır (iktiyozis linearis sirkumfleksa). Yüz, skalp ve kaşlarda seboreik dermatit benzeri skuamalar vardır. "Bambu kamışı" kıllar da denilen trikoreksis invajinata en belirgin saç defektidir. Tipik 
saç bulguları geç ortaya çıkabilir bu nedenle bu bebeklerde saç incelemeleri aralıklı olarak tekrarlanmalıdır. Trikoreksis invajinata tanısı ışık mikroskobu ile kolayca konur. Atopi, astım veya IgE yüksekliği bu sendroma eşlik eder. Bu bebeklerde sıklıkla hayatın ilk yılında büyüme geriliği, hipernatremi, hipotermi, sık tekrarlayan enfeksiyonlar ve sepsis görülebilir. Bu dönemde mortalite oldukça yüksektir $(8,9)$. Ülkemizde yayımlanan bir raporda, NS'li iki erkek kardeşten birinde aynı zamanda mental retardasyon görüldüğünden, diğer kardeşin mental olarak normal ama davranış sorunlarına sahip olduğundan bahsedilmiştir (10). Bizim vakamızda da benzer şekilde anne ve babanın akraba oluşu, hastanın doğduğundan beri bu tanıya sahip oluşu ve kendisi gibi NS'li bir erkek kardeşinin 9 aylıkken ölüşü genetik geçişi destekler niteliktedir. Ailenin ölen çocuklarının ölüm sebebi konusunda yeterince bilgi sahibi olmaması dikkat çekmekle birlikte, muhtemel ölüm sebebinin literatürle uyumlu olarak büyüme geriliği, hipernatremi, hipotermi, sık tekrarlayan enfeksiyonlar ve sepsisten herhangi birisinin olabileceğini düşünmekteyiz.

\section{SONUÇ}

Moleküler genetiğin kliniğe girmesi, gittikçe daha çok sayıda hastalığın incelenmesine olanak vererek etiyoloji-patogenez ilişkisini aydınlatmış, tanı ve tedavide yeni ufuklar açmıştır. Mental retardasyon etiyolojisinde suçlanan genetik boyutun, olgumuzdaki NS hastalığının genetik yönüyle ilişkilendirilebileceği ilerideki çalışmalar önem arz etmektedir. Olgumuz bu sebeple NS'li çocukların ve ailelerinin konsültasyonliyezon psikiyatrisi çerçevesinde takibinin önemli olduğunu vurgulamak açısından da sunulmaya değer bulunmuştur.

\section{KAYNAKLAR}

1. Paller AS, Mancini AJ. Hereditary Disorders of Cornification, in Hurwitz Clinical Pediatric Dermatology. 4th ed. China: Elsevier Saunders; 2011:92-107.

2. Erdoğan AG, Balaban D, Derviş E, Karaoğlu A. Aminoasidürinin eşlik ettiği Netherton sendromlu bir olgu. Türkderm. 2006;40(3):108-10.

3. Emre S, Metin A, Demirseren D, Yorulmaz A, Onursever A, Kaftan B. Two siblings with Netherton syndrome. Turk J Med Sci. 2010;40(5): 819-23.

4. Bozdağ KE, Altun Y, Ermete M. Netherton sendromu: olgu sunumu. Turkiye Klinikleri J Med Sci 2004;24(1):94-7. 5. Schmuth M, Gruber R, Ellias PM, Williams ML. Ichthyoses update: towards a functiondriven model of pathogenesis of the disorders of cornification and the role of corneocyte proteins in these disorders. Adv Dermatol. 2007;23:231-56.

6. Williams ML, Elias PM. Ichthyosis: genetic heterogeneity, genodermatoses and genetic counseling. Arch Dermatol. 1986;122(5):529-31.

7. DiGiovanna JJ, Robinson-Bostom L. Ichthyosis: etiology, diagnosis and management. Am J Clin Dermatol. 2003;4(2):81-95

8. Judge MR, Morgan G, Harper JI. Clinical and immunological study of Netherton's syndrome. Br J Dermatol. 1994;131(5):615-21.

9. Chavanas S, Bodemer C, Rochat A, Hamel-Teillac D, Ali $\mathrm{M}$, Irvine $\mathrm{AD}$ ve ark. Mutations in SPINK5, encoding a serine protease inhibitor, cause Netherton syndrome. Nat Genet. 2000;25(2):141-2.

10. Başgül ŞS, Kartal S, Elmi HC. Netherton sendromunun psikiyatik bulguları. Göztepe Tip Derg. 2010;25(3):13841. 